\title{
MARKET CLIMATE AND CUSTOMER PREFERENCES TOWARDS FRANCHISOR OF ISLAMIC KINDERGARTEN IN SHAH ALAM
}

\author{
Nur El Ikhsan \\ Institut Ilmu Sosial dan Manajemen STIAMI \\ Email: nurelikhsan@gmail.com
}

ARTIICLE INFO ABSTRACT

Keywords:

Market Climate, Preferences, Islamic

Kindergarten, Education, Shah Alam
This study aims to identify market climate and customer preferences of people around Shah Alam, Malaysia towards franchisor of Islamic kindergarten. The research method used is quantitative approach and questionnaires are distributed to 40 parents around Shah Alam who have children and putting their children to have pre-education among 3 Islamic kindergarten brand. The result of this study explained that most consumers engage their children to pre institutions the school grounds to increase the ability and social interaction. The main consideration consumers in choosing pre-school education are the type of program services offered and teacher skills and knowledge. While biggest decision maker was the husband. Price sensitivity is low with costs incurred for pre-school activities people feel suitable is more than RM 200 per month. Lastly, if consumers are not satisfied then the action taken is complain directly to the pre-school and directly stop using the service.

\section{INTRODUCTION}

Franchise preschool educational institution has become a booming and highly competitive business in Malaysia since government increased their attention on preschools education in the early 1990s. There has been increasing participation by the private sectors in education at all levels with an increase in private schools enrollment at both the pre-schools and primary levels (Role of Private Sector, 2005). The quality of the educational staffs, teaching materials and consistency of teaching styles are the main concern in creating a better study environment for all children.

In Malaysia, have a lot of franchise preschool educational, but in this case study, we focus to top franchisor, which are Little Caliphs International Sdn Bhd, Genius Aulad Learning Consultancy Sdn Bhd and Brainy Bunch Islamic Montessori. Little Caliphs International Sdn. Bhd. is a licensing company which sell its core program, called The Little Caliphs Program. The Little Caliphs Programme (TLCP) is an IslamicEnglish-Creative preschool programme that helps preschool children to realize their best spiritual, cognitive, socio-emotional and physical potential. Unlike other conventional preschool programme, TLCP has a set of proven creative methodologies for teaching the children the meaningful foundation of Islam, learning and living skills in an integrative and holistic manner.

To equip teachers with effective teaching skills, TLCP offers series of trainings on teaching content and methodologies. TLCP also comes with business start-up and operation package for Muslim entrepreneurs to open and operate their own Islamic-English-Creative kindergarten or child enrichment centre.

Meanwhile, GENIUS AULAD leading preschool was established with the dream of bringing quality of preschools to a greater high based on Islamic principles, English emphasis, and cheerful well-designed facilities.

Since December 2000, GENIUS AULAD has swiftly broken preschool norms around the nation especially in its educational approach and enthusiastic children events and has risen to become the nation's best. Thus, with the motto "Lessons Beyond Classroom", GENIUS AULAD has stretched itself further than just preschool syllabus and extensively broaden the teaching horizon's into GENIUS AULAD's very own audio and 
video productions, exciting books and material publications, as well as development of programs for its very own interactive whiteboards, the Assist Board.

Then, Brainy Bunch has its own stories. In 2004, their lifelong dream became more pressing with the birth of their firstborn and later fuelled by the births of their two other children in 2005 and 2008 respectively. Just as having a baby changes every parent's life, it further realigned their founders'. Overnight, their greatest concerns became centred around providing only the best for their children and giving them every opportunity to excel in life - linguistically, intellectually, physically, socially and emotionally, and especially, spiritually.

Finally, in January 2008, unable to deny this aspiration any longer, they bravely embarked on the New Year by purchasing their first kindergarten in Kajang, Malaysia. With a dream of an ideal world held very close to their hearts and supported by the strong desire to give back to the community, their first kindergarten was developed with so much thought and such care to become their children's and their children's friends' dream school, and then later to act as the pilot for the Brainy Bunch franchise.

Since kindergarten businesses are rapidly growing and many beginner entrepreneur looking for this business, number of kindergarten established are scattered everywhere. That is the reason why, RESEARCHER choose "Market Climate and Customer Preferences towards franchisor of Islamic kindergarten in Shah Alam" as my study report title.

\section{LITERATURE REVIEW}

\section{Franchise Preschool Educational Institution}

Nowadays, franchising has become a popular business strategy in many industries around the world (Inma, 2005; Sorenson and Sorensen, 2001; Dant \& Kaufmann, 2003). According to Lawrence and Oakley (2005), franchising is a system for expanding a business and distributing goods or services and an opportunity to operate a business under a recognized brand name. A franchise occurs when franchisor (business) licenses its business idea or concept to franchisee (person or group who agrees to operate the business) according to the franchise agreement and pays loyalty to the franchisor (Inma, 2005).

For instance, there are two types of franchising: (1) business format and (2) product or trade name. According to Lawrence et al. (2005), business format franchises not only sell the franchisor's product or service, with the franchisor's trademark, but also run the business according to the system provided by the franchisor. However, according to Audhesh \& Michael (2009), successful franchisors do not just sell products and services. They should perfect a business system and then sell their know-how (skills and procedures) and benefits of the business system to prospective franchisees and subsequently to customers.

One of the major challenges faced by franchisors in knowledge based economy is the effective implementation of knowledge management (Sorenson, 2001; Watson, Stanworth, Healeas, Purdyb \& Stanworth, 2005; Paswan \& Witmann, 2009). Knowledge is the most valuable resource to create and sustain competitive advantage (McFayden \& Canella, 2004; Morgan \& Hunt, 1997), to enable franchise units to become more efficient (Darr et al., 1995), and it is vital for new product development and success (Van der Bij, Song, \& Weggeman, 2003). Moreover, according to Watson et al. (2005), a franchisor is no longer principally concerned with selling goods, but rather, information and knowledge. Thus, managing the knowledge effectively within and across the organization is important to ensure franchise system success.

In other words, to ensure its success, franchise preschool educational institutions should develop an environment which is suitable for knowledge management implementation. In this context, the environment should allow fostering knowledge creation, storage, transfer and application between franchisor and franchisees, across franchised units, franchisor and company-owned units, and among all members in the network such as suppliers, customers and other organizations (Augier et al., 2001).

So this research talked more about effects of knowledge management on franchise preschool educational institutions. It shows that environment of kindergarten business like the economic conditions/household resources consistently link to performance of preschool institutions. But these households are restricted to two types of households: (1) Those with a householder with other relatives in the household, a spouse of the householder, and own children of the householder (i.e. two adults and their children); and (2) Households with a householder with other relatives in the household, and own children of the householder (i.e. one adult and his/her

Nur El Ikhsan (Market Climate And Customer Preferences Towards Franchisor Of Islamic...) 
children). Developing a good environment will maximizes application of knowledge management, and then can maintain franchise system in this kindergarten business.

\section{Pre-school Institutions in Malaysia (Dr. Zainurin Bin Dahari, 2011)}

Pre-school is an institution where children are prepared to enter a social and educational based environment. Pre-school may be considered as preparatory class for year one of primary school. The pre-schools in Malaysia normally take in children from as early as three to six years old. The history of early childhood education in Malaysia could be traced back to the earliest pre-school institutions in Malaysia, which were introduced and managed by Christian missionaries.

In those days only children of the rich and aristocrats have the privilege of early childhood education. Only in the 1970s, the Malaysian Ministry of Rural Development introduced government funded pre-schools, commonly known as KEMAS, to children of low income family living in rural areas (Adnan Abd. Rashid,1993). Aid for early childhood education also came from Asia Foundation, which funded pre-school projects known as "HEADSTART" in several rural towns in 1969. The first formal and pioneer pre-schools were launched by the Minister of Education in 1992, which started with 1,131 annex pre-school classes in Government primary schools (Puteri Zabariah et al, 2005).

To unify and standardize early childhood education programs run by the various sectors, the national Preschool Curriculum was introduced and became part of the 1996 Education Act. For Malaysia to be a developed nation by 2020, the government must ensure quality pre-schools for all children in Malaysia. This is because children are the nation's most valuable asset, as today's children are leaders of tomorrowe. In the last decade, pre-schools have mushroomed all over the country. Pre-schools in Malaysia are so diverse due to the country's multicultural society and individual needs.

Pre-school institutions may be differentiated based on the medium of instruction (which may be in English, Malay or Chinese), the curriculum approaches, religious orientation, origin (i.e. local or international), or political affiliations (Puteri Zabariah et al, 2005). Current trends identify pre-schools as either branded, usually a local or foreign franchise, or non-branded, which is usually run by individual proprietors. The various types of pre-schools are listed but not limited to the list below:

- Ministry of Education pre-school annexes in national primary schools

- KEMAS (by the Ministry of Rural Development)

- Tadika Perpaduan (by the Ministry of National Integrity)

- KAFA (by State Islamic Religious Department)

- International Schools

- NGO pre-schools, e.g. ABIM

- Private pre-schools, e.g. Montessori, SmartReader, COSMOTOTS, and others.

- Religious based pre-schools, e.g. Tahfiz Al-Qur"ean and church-based kindergartens.

- Language based, e.g. Chinese medium, English medium, usually privately run.

- Hybrid pre-schools, e.g. those using a combined curriculum of Islamic studies, English and Mathematics.

- Holistic pre-schools, e.g. those using a combined curriculum of Tahfiz Qur'an, English, Computer studies and Mathematics.

- Politically-affiliated pre-schools, e.g. PASTI by the Islamic Party of Malaysia (PAS), and Chinese preschools by the Malaysian Chinese Association (MCA).

\section{The Roles and Contributions of Pre-schools}

Pre-school is a child's first formal educational experience and is a very special and important phase in the child's life. Besides preparing a child for year one of primary school, pre-school also provide early training for moral values and social intelligence. According to the Malay saying, "Melentur buloh biar dari rebung", which is translated as "To shape a bamboo tree, it must be bent or molded while they are still shoots", it means that it is easier to teach, shape or to instill moral values and discipline in children while they are young.

Children are like new computers with unlimited memory space. "A child's entry gate to education must be of memories filled with enjoyable challenging and fun-learning experience" (Chun, 2007, p.1). According to 
Krupicka (2005) they perform better in literacy tests than their peers without pre-school experience. Pre-school educated children are also more likely to graduate from college or university, and are less apt to get into trouble or participate in criminal activities such as vandalism, drug problems, truant or gangsterism. Studies indicate that, for every dollar invested in high-quality pre-school programs, the community could save as much as nine dollars in future service costs (Krupicka, 2005).

\section{Definition of franchising (Riika Lavonen, 2010)}

In order to be able to discuss more deeply about the franchising concept it is good to start with the basic terminology. First there is the introduction of the word franchise and the origin of it, then different definitions for the concept of franchising from different points of view and finally presented are the two parties in a franchise agreement; franchisor and franchisee.

Franchise is actually a loanword from the French language and it translates to freedom, privilege, and exemption (Barringer, et al. 2010, 513). Franchise, spelled as in French, is also a word in English, Finnish, Hungarian and German and has similar spelling styles in other world languages (sanakirja.org).

The term Franchising can be opened up in several ways. Bennett, et al. (2008, 9) quoting Cheryl Babcock, director of the International Institute for Franchise Education as Nova Southeastern University in Fort Lauderdale gives quite comprehensive definition and also notes the existence of the two parties in the operation (Tuunanen 2005,19$)$ takes more technical point of view in his version whereas Keup $(2007,55)$ sums the term in a practical way. The different ways to describe the term franchising are in Figure 1.

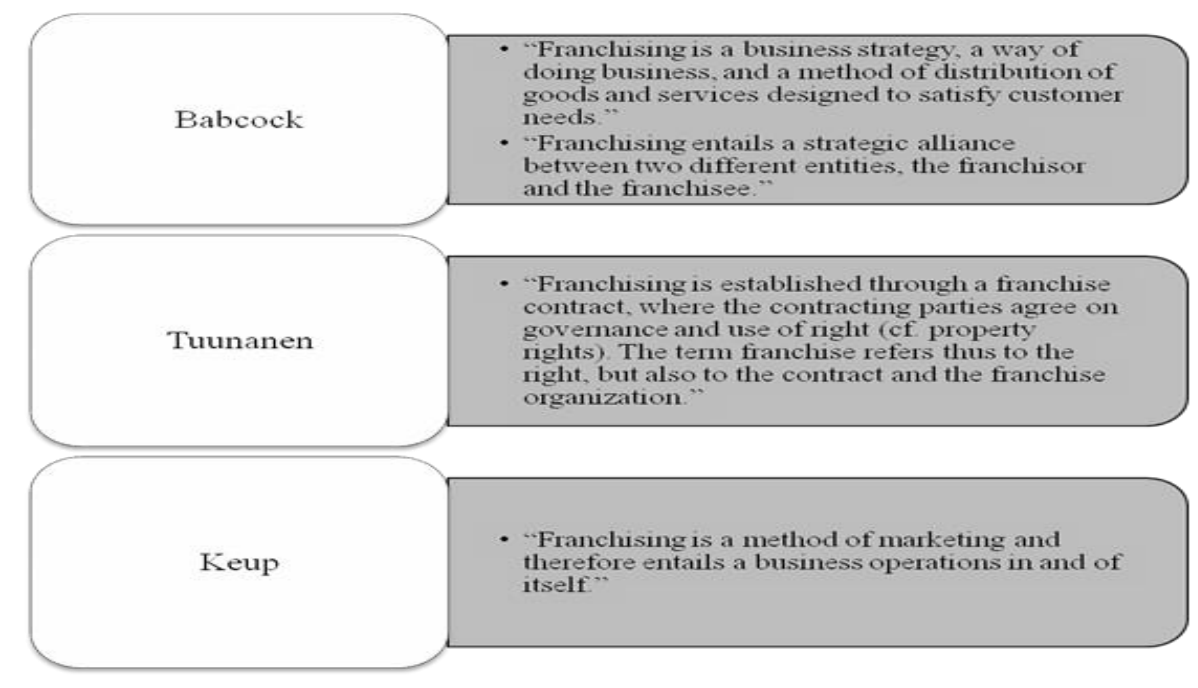

Figure 1. Franchising definitions from different perspectives

Franchisor is usually the creator of the business concept, the one that has developed and launched the operations (Tuunanen 2005, 19). Once successful in the business, the business owner lends rights to do business under the same name to another business owner using the original method and/or trademark for a predetermined period of time set in a contract (Barringer, et al. 2010, 513). Franchisee is the receiver of the right to conduct business invented by the franchisor. Franchisee can also be called a franchise owner (Tuunanen 2005, 19). (Bennett, et al. 2008, 9) quotes Babcock summarizing the roles of the two parties: "Franchisee pays the franchisor a royalty fee and often an initial fee for the right to utilize the franchisor's brand name, operating system, and ongoing support, and agrees to conform to quality standards."

\section{METHODOLOGY}

Research is a process that people start when they need to find out about a certain issue in a systematic way and in this way increase their knowledge of the issue. The collection of data alone does not compose a research; it has to be collected systematically and with a clear purpose. Also an assembly of data from different 
sources in one document with bibliography is not enough to make it a research; this is a part of the research that is concluded with interpretation of what the data tells (Saunders, et al.2009, 320).

The descriptive research method uses observation and surveys. In this method, it is possible that the study would be cheap and quick. It could also suggest unanticipated hypotheses (Saunders, et al., 2003). So, since researcher conducted the survey through a questionnaire, namely regarding the market climate and customer preferences towards franchisor of Islamic kindergarten in Shah Alam this study is called a descriptive study. In addition, observation had been done and also the researcher gets data from secondary sources because it is very easily obtained and low cost.

This research uses nonprobability sampling because researcher hasn't been definitively determines the target population will be discussed. Target populations are parents that have their children in these three kindergartens and also randomly choose parents who don't put their children at any kindergarten yet. All of them will be selected randomly using the simple random sample method.

\section{RESULT AND DISCUSSION}

Data collected from the questionnaire in this research is processing by IBM SPSS version 22.0. There are a few steps in entering the data into the SPSS system. Firstly, fill up the variable view. Fill in all the information for example name, label, and values, once finish your key-in data, then click data view. In data view, all raw data from respondents which the data obtain from questionnaire. The questionnaire is divided into three sections, where each of the section has its own objectives to accomplish.

\section{Personal Information}

Majority of people around Shah Alam are Pre-School user (87.5\%). It means that people in Shah Alam concern about pre-school education for their children, so in average, most of parents send their children to kindergarten.

Majority of pre-school service users aged 28-32 years (25.0\%) and follows by aged 33-37 (22.5\%). Most of them are young parents who just got married and the rest are young executive. Further, the majority of respondents were male (47.5\%). Although, women are most frequently deliver their children to school and waiting for the husband. Generally male parent (husband) only deliver and pick up yet rarely waiting for her son. And all service users pre-school that a respondent has a job. The largest percentage of job of pre-school service users are administrative workers (27.5\%) and professional (20\%). $7.5 \%$ are housewives and pension and the remaining answered others. Which belongs to the category other professional workers such as doctors, researchers, designers.

\section{Market Climate}

The majority of parents who enter their children to preschool is medium-sized family, which has 2 or 3 children (17.5\% or $30 \%)$. Parents who have four child by 15.0 percent, while the parents of 5 children by 10 percent. Then, expenditure for household of less than RM 3000 ringgit by 27.5 percent. There are 9 persons or parents have RM 4000 - RM 4999 of their take home income. This shows that most of parents of pre-school users are low to middle income household.

Further, educational expense spent by parents per month for a child in range RM 300 - RM 399 (27.5\%). Parents in this range have high level of concern about children's education. While for the range of RM 400 and above by 20.0 percent. This group usually are parents of high level of income and also those who have children more than 3, because assume for every child they spend RM 12o and above. Usually children are not in direct supervision a day for 7-9 hours 42.5 percent. This is because respondents in Shah Alam have a job almost all-day, compare to Indonesia, where most of female are housewives. However, there is a tendency habit of leaving children more than 5 hours a day. It is indicated by the percentage of parents do not supervise children directly as much as 41.4 percent.

The majority of respondents entrust their children to husband or wife $(32.5 \%)$, if they can't supervie their children directly. The rest are divided on the school (17.5\%), grandmother or grandfather $(15.0 \%)$. It happens because most of parents in Shah Alam are working outside at least a husband or wife.

Based on the results of the questionnaire, can be seen that the consumers get the information derived from various sources. Respondents were allowed to choose more than one choice. The majority of respondents 
stated that the information regarding the pre- school they get from colleague/friends, the number of percentage at 22.5 percent. When they feel the need to enter their children into pre-school, they would ask friends first and came to own the preschool institutions, and seek information directly. This is done to get more information complete, and they can see first hand the conditions of the pre-school. This stage, pre-school institution employees play an important role. Because the first impression will influence consumer decisions.

Other resources are billboards or banners that by 7.5 percent. Because usually, information about where the pre-school they get from billboards or banners that are in strategic places they used to skip ahead or institution pre-school itself. Meanwhile, 7.5 percent of information obtained from family and relatives. In general, Little Caliphs International Sdn Bhd got highest percentage (40\%) who answer LCISB only, but there are some respondents answer more than 1 answer, so it means LCISB can earn higher percentage.

\section{Customer Preferences}

Below are results regarding customer preferences toward particular issue. Highest-Highest indicate that parents assume the issue is highest priority, for example education program gets highest priority in parents mind and got $21 \%$ of parent's answer. And lowest-lowest means that parents assume the particular issue is less important than other.

Tabel 1. Customer Preference Indicators

\begin{tabular}{|c|c|c|c|c|c|c|c|c|}
\hline \multirow[b]{2}{*}{ Category } & \multicolumn{8}{|c|}{ Indicators } \\
\hline & $\begin{array}{l}\text { Education } \\
\text { Program } \\
\text { and Service } \\
\text { Offered }\end{array}$ & $\begin{array}{l}\text { Affordable } \\
\text { Price }\end{array}$ & $\begin{array}{l}\text { Promotional } \\
\text { Tools }\end{array}$ & Location & $\begin{array}{l}\text { Employees and } \\
\text { Teachers }\end{array}$ & $\begin{array}{l}\text { Service } \\
\text { Process }\end{array}$ & Facilities & $\begin{array}{l}\text { If Not } \\
\text { Satisfied }\end{array}$ \\
\hline Highest-Highest & 60.0 & 14.3 & 8.8 & 28.6 & 14.7 & 17.6 & 23.5 & 5.7 \\
\hline Middle-Highest & 11.4 & 11.4 & 14.7 & 14.3 & 29.4 & 23.5 & 11.8 & 8.6 \\
\hline Lower-Highest & 11.4 & 25.7 & 14.7 & 17.1 & 11.8 & 8.8 & 2.9 & 48.6 \\
\hline Medium & 5.7 & 22.9 & 29.4 & 17.1 & 14.7 & 8.8 & 20.6 & 34.3 \\
\hline Upper-Lowest & 8.6 & 14.3 & 11.8 & 14.3 & 5.9 & 11.8 & 14.7 & 2.9 \\
\hline Lowest-Lowest & 2.9 & 5.7 & 5.9 & 2.9 & 5.9 & 17.6 & 11.8 & \\
\hline
\end{tabular}

Source: Primary Data, 2017

Tabel 2-A dan B Customer Preference Indicators (Continued)

\begin{tabular}{|l|r|r|r|r|r|r|r|r|}
\hline \multirow{2}{*}{ Category } & \multicolumn{9}{|c|}{ Indicators } \\
\cline { 2 - 9 } & $\begin{array}{l}\text { Religious } \\
\text { Education }\end{array}$ & $\begin{array}{l}\text { Computer } \\
\text { Education }\end{array}$ & $\begin{array}{l}\text { Foreign } \\
\text { Language }\end{array}$ & $\begin{array}{l}\text { Development } \\
\text { of Talents, } \\
\text { Hobbies }\end{array}$ & $\begin{array}{l}\text { Development } \\
\text { of Motor Skill }\end{array}$ & $\begin{array}{l}\text { Development } \\
\text { of } \\
\text { Interaction } \\
\text { Skill }\end{array}$ & $\begin{array}{l}\text { Report } \\
\text { of Child }\end{array}$ & $\begin{array}{l}\text { Education } \\
\text { Consultancy }\end{array}$ \\
\hline Strongly-Important & 82.9 & 28.6 & 17.1 & 38.2 & 48.6 & 45.7 & 45.7 & 17.6 \\
\hline Important & 14.3 & 37.1 & 42.9 & 55.9 & 20.0 & 40.0 & 34.3 & 52.9 \\
\hline Neutral & 2.9 & 31.4 & 34.3 & 5.9 & 28.6 & 14.3 & 17.1 & 29.4 \\
\hline Unimportant & 0 & 2.9 & 5.7 & 0 & 2.9 & 0 & 2.9 & 0 \\
\hline
\end{tabular}

B.

\begin{tabular}{|c|c|c|c|c|c|c|}
\hline \multirow[t]{2}{*}{ Category } & \multicolumn{6}{|l|}{ Indicator } \\
\hline & $\begin{array}{l}\text { Shuttle } \\
\text { Service }\end{array}$ & $\begin{array}{l}\text { Location } \\
\text { Close to } \\
\text { Residence/ } \\
\text { Office } \\
\end{array}$ & $\begin{array}{l}\text { Ample } \\
\text { Location }\end{array}$ & $\begin{array}{l}\text { Women } \\
\text { Instinct }\end{array}$ & Rest Area & Easy Process \\
\hline Strongly Important & 18.2 & 36.4 & 21.2 & 30.3 & 24.2 & 39.4 \\
\hline Important & 30.3 & 30.3 & 48.5 & 33.3 & 21.2 & 39.4 \\
\hline Neutral & 15.2 & 21.2 & 30.3 & 30.3 & 30.3 & 18.2 \\
\hline Unimportant & 21.2 & 12.1 & 0 & 6.1 & 15.2 & 3.0 \\
\hline $\begin{array}{l}\text { Strongly } \\
\text { Unimportant }\end{array}$ & 15.2 & 0 & 0 & 0 & 9.1 & 0 \\
\hline
\end{tabular}

Source: Primary Data, 2017 
Services can lead to satisfaction or dissatisfaction. On this question, respondents were allowed to choose more than one reply. In the event of dissatisfaction with the various measures will consumers do. Action is the most widely performed complaints directly to the pre-school staffs $(42.5 \%)$. To overcome this problem, the preschool management should provide all staffs the media or tools/equipment to tackling complaints properly. The number of consumers who will stop using service and look for another alternative are 30 percent.

Tables shown below are preferences of parents toward kindergarten issue, so respondents had choose which issue is strongly important for them and which one is not important and so on. For example, about religious education, $72.5 \%$ respondents said that that's very important thing to consider when they choose kindergarten franchise. Complete results are shown below:

Tabel 3. Preferences of Parents Toward Kindergarten Issue

\begin{tabular}{|c|c|c|c|c|c|c|c|}
\hline \multirow{2}{*}{$\begin{array}{l}\text { Number of } \\
\text { Children }\end{array}$} & \multicolumn{7}{|c|}{ Current expenditure in household } \\
\hline & $\begin{array}{c}\mathbf{R M} \\
<\mathbf{3 0 0 0}\end{array}$ & $\begin{array}{c}\text { RM } \\
3000- \\
3999\end{array}$ & $\begin{array}{c}\text { RM } \\
4000- \\
4999 \\
\end{array}$ & $\begin{array}{r}\text { RM } \\
\mathbf{5 0 0 0 -} \\
\mathbf{5 9 9 9}\end{array}$ & $\begin{array}{r}\text { RM } \\
6000- \\
6999\end{array}$ & $\begin{array}{c}\text { RM } 7000 \\
\text { and } \\
\text { above }\end{array}$ & Total \\
\hline 1 & 4 & 0 & 0 & 1 & 0 & 0 & $5(14.7 \%)$ \\
\hline 2 & 1 & 4 & 2 & 0 & 0 & 0 & $7(20.6 \%)$ \\
\hline 3 & 1 & 2 & 5 & 1 & 2 & 1 & $12(35.3 \%)$ \\
\hline 4 & 3 & 0 & 1 & 2 & 0 & 0 & $6(17.6 \%)$ \\
\hline 5 & 1 & 0 & 1 & 0 & 0 & 2 & $4(11.8 \%)$ \\
\hline Total & 10 & 6 & 9 & 4 & 2 & 3 & $34(100 \%)$ \\
\hline
\end{tabular}

Crosstab above shows that out of the 5 who have one child. 4 are low income which is less than RM 3000. And parents who have 2 children, their average household income are RM 4000. First, we can conclude that incomes are having direct implication with number of children, so for those who have more children, then their parents will try to get more income. Second, generally, in Shah Alam area, household income are middle income which is range from RM 3000-4000 (16 respondents out of 34).

Tabel 4 Cross Tab Number of Children*Cost on Pre-School Education/Month

\begin{tabular}{|c|c|c|c|c|c|}
\hline $\begin{array}{c}\text { Number of } \\
\text { Children }\end{array}$ & \multicolumn{5}{|c|}{ Cost on pre-school education/Month } \\
\hline & $\begin{array}{c}\text { RM 100- } \\
\mathbf{1 9 9}\end{array}$ & $\begin{array}{c}\text { RM } \\
\mathbf{2 0 0 - 2 9 9}\end{array}$ & $\begin{array}{c}\text { RM } \\
\mathbf{3 0 0 - 3 9 9}\end{array}$ & $\begin{array}{c}\text { RM 400 } \\
\text { and } \\
\text { above }\end{array}$ & Total \\
\hline $\mathbf{1}$ & 1 & 2 & 1 & 1 & $\mathbf{5 ( 1 5 . 2 \% )}$ \\
\hline $\mathbf{2}$ & 1 & 3 & 2 & 0 & $\mathbf{6 ( 1 8 . 2 \% )}$ \\
\hline $\mathbf{3}$ & 0 & 4 & 6 & 2 & $\mathbf{1 2 ( 3 6 . 4 \% )}$ \\
\hline $\mathbf{4}$ & 2 & 0 & 2 & 2 & $\mathbf{6 ( 1 8 . 2 \% )}$ \\
\hline $\mathbf{5}$ & 1 & 0 & 0 & 3 & $\mathbf{4 ( 1 2 . 1 \% )}$ \\
\hline Total & $\mathbf{5}$ & $\mathbf{9}$ & $\mathbf{1 1}$ & $\mathbf{8}$ & $\mathbf{3 3 ( 1 0 0 \% )}$ \\
\hline
\end{tabular}

According to Krupicka (2005) children who got pre-school education will perform better in literacy tests than their peers without pre-school experience. Pre-school educated children are also s likely to graduate from college or university, and are less apt to get into trouble or participate in criminal activities such as vandalism, drug problems, truant or gangsterism. Studies indicate that, for every dollar invested in high-quality pre-school programs, the community could save as much as nine dollars in future service costs (Krupicka, 2005). 
From crosstab above, most of parents in Shah Alam spend at least RM 100 per children for invest in childhood education. They know the important of early education so they are not hesitate to spend more. But some of them spend more than RM 100. For example, parents near Seksyen 7 Shah Alam, in average they spend RM 350-400 per children per month. The reason why the cost is very high because the school that they send their children is holistic kindergarten who have complete curriculum and some of them also provide day care until afternoon (after office hour)

Tabel 5. Cross Tab Pre-School User*Children Not In Supervision

\begin{tabular}{|c|c|c|c|c|c|}
\hline & & & & & \\
\hline $\begin{array}{c}\text { Pre School } \\
\text { User }\end{array}$ & \multicolumn{5}{|c|}{ Children not in supervision } \\
\hline & $\mathbf{1 - 3}$ Hours & $\begin{array}{c}\mathbf{3 - 5} \\
\text { Hours }\end{array}$ & $\begin{array}{c}\mathbf{5 - 7} \\
\text { Hours }\end{array}$ & $\begin{array}{c}\text { H-9 } \\
\text { Hours }\end{array}$ & Total \\
\hline Yes & 4 & 4 & 9 & 17 & 34 \\
\hline Total & $\mathbf{4}$ & $\mathbf{4}$ & $\mathbf{9}$ & $\mathbf{1 7}$ & $\mathbf{3 4}$ \\
\hline
\end{tabular}

According to Hollowell (1994), early childhood education, usually defined as "pre-school provides the best opportunity to engage children in active instruction and build the foundation for future learning. So, from 60 questionnaires disseminated to respondents, only 40 questionnaires back into researcher, and 34 of them are preschool user. It shows that majority parents in Shah Alam understand that pre-school services offer by provider can build the foundation for future learning for their children and at the same time, enhance their interaction skill with others.

From these parents, we can say that they are working outside and don't have much time with their children. This is one reason for them why they use service offered so instead of their children with nurse or maid, their children can get knowledge and affection while they can't beside their children.

\section{CONCLUSION AND RECOMMENDATION Conclusion}

Based on the analysis that had been done, the data showed that consumer formal pre-school in Shah Alam is families who have one or two children, a husband and wife aged around 28-37 years, the husband and wife's education is Degree and above. The majority of working background are private sector employees and administrative workers and wives also. The average expenditure per month is around RM 3000 - RM 4000.

Most consumers engage their children to pre institutions the school grounds to increase the ability and social interaction. On average parents not supervise their children for 7-9 hours per day, and supervision entrusted to the husband or wife. Consumers obtain information from colleagues and friends, some of them from website or banner. The main consideration consumers are choosing pre-school education and the type of program services offered. Biggest decision maker was the husband. Costs incurred for pre-school activities are more than RM 200 per month. If consumers are not satisfied then the action taken is complain directly to the preschool and directly stop using the service.

Strategy can be done by observing the consumers behaviour. Pre-school institutions can offer services in the core product, additional service or product and superior products. Pricing strategies can be conducted with set two different prices; price per package, with separate pricing additional services, the distinction between nonmember and price member premises. Promotional activities can be done with the installation or set up of banners, distributing brochures, open house (open day) procurement and sponsor several activities about families or children theme event. People involved in delivering services to consumers should be the ones who experienced, friendly, trained and responsive. Physical facilities such as the playground, cafeteria and waiting room made attractive and friendly impression. Flowchart can be used to improve the quality of service 


\section{Recommendation}

This suggestion is not absolute and compulsory to follow, these are only an overview of the results analysis has been done. Its application can be different on each pre-school and parents perspective. It depends on the segment and target market of each of the pre-school institution, because each segments of the target market have the unique characteristics for each.

1. Pre-school institutions should really pay attention to the quality of their service. Especially, aspects that require professionalism such as timeliness, clarity and accuracy of information handling problem.

2. Pre-school institution should build two-way communication with parents as customers. Analysis of the post-purchase process suggests that if they are not satisfied then the actions taken by parents are make complaints directly or forget the service and find the new one.

3. The majority of customers get information about upcoming kindergarten from colleagues or their friends. Pre-school parties can take advantage of this opportunity to provide the best service. And at the same time can use referral strategy to attract new students. They should pay the parents who bring their parents to particular kindergarten as a commission. Website, as one of marketing tools also can maximize since nowadays almost all parents have smartphones at the pocket. It can be designed by professional one so the website can be interesting in the eye of customers, because it gives information to customers rapidly.

4. Pre-school institutions should conduct customer satisfaction research continuously.

5. Pre-school should conduct training to improve teaching quality. Teaching quality can be one of the attractions for pre-school.

\section{References}

Definition of Franchising: Accessed on En.wikipedia.org/wiki/franchising 13 June 2013

Definition of Licensing: accessed on En.wikipedia.org/wiki/license 24 June 2013

Background of Little Caliphs International Sdn Bhd: accessed on www.littlecaliphs.com 10 June 2013

Background of Genius Aulad Learning Consultancy Sdn Bhd: accessed on http://www.geniusaulad.com.my/main.html 17 August 2013

Analisis Preferensi Calon Konsumen terhadap Atribut Jasa Program Sarjana Penyelenggaraan Khusus (Studi

Kasus Program Diploma di Kotamadya Bogor): accessed on http://repository.ipb.ac.id/bitstream/handle/123456789/17958/H08efs.pdf?sequence=3 17 August 2013

Background of Brainy Bunch International Islamic Montessori Bhd: accessed on http://www.islamicmontessori.com/ 18 August 2013

How to develop data sampling: accessed on http://www.bcps.org/offices/lis/researchcourse/develop_data_sampling.html\#sample 18 August 2013

\section{Journal}

The Business Round table, \& corporate voices for working families. (2013). Early Childhood Education: A Call to Action from the Business Community: A longitudinal study, page 1-9.

Norwegian Ministry of Education and Research. (2007). Education-from Kindergarten to Adult Education: page $1-28$.

Lavonen, Riika. (2010). Franchising as a Potential Growth Strategy for a Small Enterprise: Bachelor Thesis, page 1-49.

L. Howard, Katila. (2011). Early Education from a Parental Perspective: A qualitative study. 
Howe, Chu. Chee, Shun, Lim. Xi, Yi, Lim. XTN, Hui, See. Chia, Pien, Yeoh. Boon. (2011). Organizational Factors for The Implementation of Knowledge Management in Franchise Preschool Educational Instituition: Bachelor Thesis, page 32-34.

Purnamasari, Maharani. (2006). Perilaku Orangtua Pengguna Jasa Pendidikan Pra Sekolah Jalur Non Formal di Bogor Tengah: Skripsi untuk Sarjana Ekonomi. Institut Pertanian Bogor.

Dahari, Zainurin. Factors that Influence Parents' Choice of Pre-Schools Education in Malaysia: An Exploratory Study.Kuala Lumpur: IIUM, 2011.

Sharon L. Kagan and Kristie Kauerz. Making the Most of Kindergarten Trends and Policy Issues. Columbia University.

Jane Nunis, Sadie. The Business of Character Building at an Early Age. Singapore: Page 22-25. February 2012.

Saunders, Mark - Lewis, Philip - Thornhill, Adrian 2009. Research methods for business students, fifth edition. Financial Times / Prentice Hall.

Barringer, Bruce R. - Irelnad, Duance R. 2010. Entrepreneurship, successfully launching new ventures. USA. Pearson Education, Inc.

Abbas, Asghar. Abdul Ghaffar Tahir. Ghayoor Ahmad Gazali. Montessori and Kindergarten System of Education in the Development of Social and Language Skills of Children. European Journal of Business and Social Sciences, Vol. 1, No. 12, pp 17-24, March 2013. 